\title{
The Ability Of Teachers To Organize Science Learning For Early Childhood
}

\author{
Anita Yusa \\ ${ }^{a}$ Lecturer in the Department of Teacher Education Early Childhood Education. \\ Corresponding e-mail: anitayus.dikdas@gmail.com
}

\begin{abstract}
This paper examines contemporary issues in early childhood teacher education in Sumatera Utara. The aim of the study was to explain the teacher's abilities to organize science learning for early childhood through a constructivist approach with sample of 115 early childhood teachers in Sumatera Utara. The data collection technique is conducted through questionnaire, observation, Focus Group Discussion, and documentation analysis. The results show that (1) the teacher preparing materials and science learning media for young children at the presenter stage, (2) the teacher observed the learning activities of children at the time of learning but the data obtained has not been documented for the benefit of selfdevelopment of children, (3) the teacher asks the children questions when the child is doing the learning activities but the question has not been able to encourage children to explore and think reflectively. This study provides a new perspective to enhance the role of teachers encouraging children to become scientists.
\end{abstract}

Keywords: school-based management, effectiveness of school management, effectiveness of learning process, and school effectiveness

\section{INTRODUCTION}

The need to obtain quality children from the academic side is the priority of most families (parents). Parents want, their children have good learning skills so that children get some useful knowledge for the future of his life. These needs become the demands of parents to Early Childhood Education institutions, such as children can read, write and count. It should not be a problem because actually early childhood has kerakteristik as active learner. Characteristics of the child has a great contribution to the development of children's learning interests and is very important to be developed during this early childhood [2].

The development needs of parents and the community about early childhood impact on the growth of these institutions. There is an increase in the average number of institutions by $16 \% /$ year. Along with these growth emerged some criticisms of learning in PAUD institutions. In learning, children tend to wait and follow teacher instruction [9], learning activities are dominated by worksheets, mechanistic and highly academic [20], the condition makes children robot.

This study examines learning in early childhood institutions especially regarding the ability of teachers to manage science learning for early childhood. What teachers and children do in learning, what teachers should do in learning. How to help the Early Child to gain some knowledge, develop thinking skills, develop process skills especially related to the characteristics of children as young scientists [3].

\section{LITERATURE REVIEW}

\subsection{The Science Teaching For Early Childhood}

Early childhood often attracts everyone's attention. Early childhood has several characteristics, among them as a unique person, and has a great curiosity [7]. This feature makes early childhood known as an active individual. Therefore, early childhood needs activities, are involved in various activities to gain a planned or spontaneous learning experience.

Since infancy (infancy), children perform various activities. Children observe and respond to the phenomenon experienced every day. Children observe and respond to the environment through their sense of sight, sound, touch, smell, and taste [18]. Through this process the child gains knowledge of the existence of something, for example he knows there is himself, the mother, there is sound, taste, there is a smooth texture, rough and the other even though he has not been able to express it. In other words, early childhood can obtain their own science (science) from the environment naturally. Activities responding to the 
environment and gaining some knowledge can be expressed as a science activity.

Science as a science as well as an individual's life needs. For early childhood, science is not only important for the introduction of science (saintis) and cognitive development but also develops the skills, basic attitudes and interests of learning as well as the opportunity to know the world.

Science is a body of knowledge consisting of facts, concepts, principles, laws, theories and models that explain all events or workings of nature as well as the process of learning and the process of discovering something [12]. Science as a way of knowing about nature through the collection of data obtained by observing, exploring and concluding. This process is called a scientific inquiry.

Science deals with certain materials and materials consisting of magnets and magnets, test tubes and chemical solutions, preserved specimens and microscopes [3]. Scientists as individuals involved in the inquiry process to raise and try to answer questions about the natural environment. Science and scientific inquiri as a learning cycle for AUD as well as a guide for teachers to facilitate children perform various activities such as Figure 1 [12] .

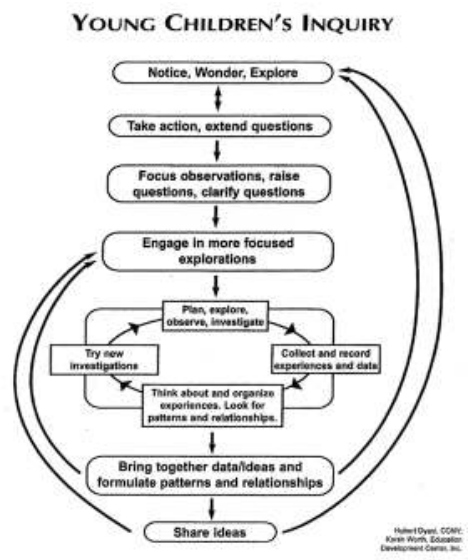

Figure 1. Science learning cycle [12]

Based on the science learning cycle for early childhood, scientific activities can provide opportunities to develop skills, such as (1) the exploration of objects and events, (2) questioning, (3) making careful observations, (4) performing a simple examination or investigation, Shape, size and number), comparing, sorting, classifying, and ordering, (5) making observation notes using, words, drawings, graphics, (6) Using various simple tools to extend observations, (7) identify patterns and relationships (8) Develop explanations and ideas, (9) cooperate with others and (10) share and discuss ideas and listen to new perspectives.

Learning science not only learns in the form of declarative knowledge in the form of facts, concepts, principles, laws, but also learns about procedural knowledge in the form of how to obtain information, how science and technology work, scientific work habits, and thinking skills. Learning science focuses on the discovery and processing of information through observing, measuring, asking questions, classifying, solving problems, and so forth.

Constructivist perspectives emphasize that knowledge is acquired and built by oneself. Constructivism is an alternative view of learning that focuses on the four major components of learning [13], ie (a) the child builds his own knowledge, (b) learning new things depends greatly on the child's early knowledge, (c) learning is greatly influenced By social interaction among people in their environment, and (d) authentic learning tasks will support meaningful learning.

\subsection{The Ability Of Early Childhood Teachers To Manage Science Teaching}

There are some experts who examine teachers' abilities. Teachers who are competent in the classroom as a teacher who: (1) perform the teaching process for a particular purpose, (2) set teaching objectives based on appropriate level of difficulty, (3) able to supervise and manage the subject matter, (4) Principles of learning, (5) have a desire to continue to grow. With regard to knowledge, it is known that teachers need to have knowledge that includes, (1) Knowledge of how to manage a classroom; (2) Knowledge of subject matter; (3) Understanding of their student sociological backgrounds" [10]. These two opinions indicate that there are several competencies teachers need to possess, such as knowledge and skills both related to learners (children) and also related content and learning objectives.

Other abilities that need to be possessed in the implementation of learning are: (1) Respect, value, and accept children and treat them with dignity at all times, (2) Make it a priority to know each child well, (3) Create an intellectually engaging, Responsive environment to promote each child's learning and development, (4) Foster children's collaboration with peers on interesting, important enterprises, (6) Develop, refine and use a (7) Facilitate the development of responsibility and self-regulation in children [18].

Science teaching as one of the teaching that is often used by teachers because this teaching can help children can explain why something happened, why and how electricity works [4]. Science as a body of knowledge and principles of learning and discovering processes [12]. For that, teachers need to have a set of skills to implement science learning for early childhood. 
Teaching is defined as an interaction of all learning components [6]; [20], and that all components interact with one another [14], with the emphasis on the environmental setting [11]. The teacher is an active facilitator, setting up educational contexts, carefully observing young children as they engage in learning, interacting when and where this encourages theory building, modifying the environment and activities based on what children do and how they interact, and supporting children in their interactions with others [3]; [16]. The quality of interaction is influenced by ... how the teachers interpret and support the needs of the children [6].

Science teaching requires teachers to do various activities. Views of teachers at the time of implementing science teaching activities as a picture or indicator of the ability of teachers in implementing science learning. The roles that teachers need to realize in science learning are (1) presenter, (2) observer, (3) quater asker and problem poser, (4) environmental organizer, (5) public relations manager, (6) document collectors (documenter), (7) classroom culture (contributer to the classroom culture), (8) theory builder [3]. Such roles can be realized in various forms of activities. The roles of the teacher in science learning through a constructivist approach are realized in the forms of activities [3]. The activity formats for each role is outlined in this Table 1.

Table 1.Teacher activities according to his or her roles

\begin{tabular}{|l|l|l|}
\hline No & Roles & Activities \\
\hline 1 & $\begin{array}{l}\text { Preparing the } \\
\text { materials in } \\
\text { science learning } \\
\text { (presenter) }\end{array}$ & $\begin{array}{l}\text { Presenting the materials, } \\
\text { choices, offering activities, } \\
\text { putting up ideas to continue } \\
\text { the activities }\end{array}$ \\
\hline 2 & $\begin{array}{l}\text { Observing the } \\
\text { children }\end{array}$ & $\begin{array}{l}\text { Observing what the children } \\
\text { are doing, listening to what } \\
\text { they are saying to discover } \\
\text { their interests, needs, and } \\
\text { understandings }\end{array}$ \\
\hline 3 & Asking questions & $\begin{array}{l}\text { Asking guided questions and } \\
\text { other questions that will } \\
\text { encourage the children to } \\
\text { look at the problem of the } \\
\text { object }\end{array}$ \\
\hline 4 & $\begin{array}{l}\text { Organizing the } \\
\text { environment }\end{array}$ & $\begin{array}{l}\text { Placing the materials in } \\
\text { indoor our outdoor } \\
\text { environment, or both }\end{array}$ \\
\hline 5 & $\begin{array}{l}\text { Managing the } \\
\text { social interaction }\end{array}$ & $\begin{array}{l}\text { Placing the children in the } \\
\text { suitable class according to } \\
\text { the proportion of teachers, } \\
\text { students, and materials. }\end{array}$ \\
\hline 6 & Documenting & Compiling, organizing, \\
\hline
\end{tabular}

\begin{tabular}{|l|l|l|}
\hline & & $\begin{array}{l}\text { utilizing, and sharing } \\
\text { information related to early } \\
\text { childhood education for the } \\
\text { development of the children }\end{array}$ \\
\hline 7 & $\begin{array}{l}\text { Developing the } \\
\text { learning culture }\end{array}$ & $\begin{array}{l}\text { Managing the behavior of } \\
\text { each individual in learning to } \\
\text { develop the learning habit. }\end{array}$ \\
\hline 8 & $\begin{array}{l}\text { Drawing up } \\
\text { conclusions of the } \\
\text { theories }\end{array}$ & $\begin{array}{l}\text { Becoming the scientist in } \\
\text { learning }\end{array}$ \\
\hline
\end{tabular}

\section{RESEARCH METHODOLOGY}

This research uses quantitative method. Data were collected using observation method with checklist and special note instrument (open note) to see how the preparation and implementation of teaching or science activities conducted by 115 kindergarten and play group teachers. The data collection is continued by focus group discussion method to deepen and clarify the necessary data related to the implementation of science teaching by involving 30 teachers divided into three groups. Data were analyzed with descriptive statistics to calculate average score, standard deviation and percentage. Data sourced from special notes and focus group discussion results are analyzed using qualitative methods to see how teachers help children interact with teachers and other children, how teachers ask questions, how children acquire and extract some knowledge through interaction.

\section{FINDINGS AND DISCUSSIONS OF RESEARCH}

The process of observation reveals various perspectives of science learning for early childhood that describes the ability of teachers to implement science learning for early childhood. The results of observation and discussion with teachers in focus group discussions show that the management of science learning conducted by teachers varies.

The results of data analysis obtained through the check list indicate that the ability of teachers to manage science learning for early childhood is in enough category with the mean observation of 12.63. This score is smaller than the ideal mean score of 13.75. This shows there are signs that science learning by early childhood education teachers has not been maximized. A good teacher's knowledge of science and learning will help teachers produce learning that enables them to pay attention to and reflect on key aspects of the phenomenon they explore. These observations Standard deviation score of 4.83 indicates that there are early childhood teachers who do their science lessons with 8 
indicators of supposed 27 indicators. The mean calculation result of each component of teacher activity in science learning for early childhood indicates that there are two activity components that have mean above ideal mean, that is component of observing children activity and drawing conclusions of the theories. In the six other teacher activities, it is known that the calculated mean is below the ideal mean. The complete mean of the mean is presented in the table for each of the science learning activities presented in Table 2 to 9 below.

The results of teacher ability analysis to manage science learning for early childhood based on science learning activities presented below.

\subsection{Preparing The Materials In Science Learning (Presenter)}

Every time science learning is done, the first time the teacher is preparing material and materials needed. The results of the analysis show that most teachers prepare materials and materials, such as informing what will be done and setting an example of how to do it. However, only a small percentage gives children the opportunity to choose activities. Materials that need to be used by children according to learning activities are prepared by some teachers according to their utilization and number of children.

Table 2. Preparing the materials in science learning (Presenter)

\begin{tabular}{|c|c|c|c|c|c|c|}
\hline $\begin{array}{l}\text { Teacher } \\
\text { activity }\end{array}$ & Indicator & $\begin{array}{c}\text { Relative } \\
\text { Frequency (sample } \\
115 \text { org guru) } \\
\end{array}$ & Persentage (\%) & $\begin{array}{l}\text { Ideal } \\
\text { mean }\end{array}$ & Mean & Sd \\
\hline \multirow[t]{4}{*}{$\begin{array}{l}\text { Preparing the } \\
\text { materials in } \\
\text { science } \\
\text { teaching }\end{array}$} & $\begin{array}{l}\text { Presents materials } \\
\text { according to the } \\
\text { proportion of } \\
\text { children: } \\
\text { ingredients }\end{array}$ & 96 & 83.48 & 2 & 1.77 & 11. \\
\hline & $\begin{array}{l}\text { Provide } \\
\text { opportunities to } \\
\text { make choices } \\
\text { (choices) }\end{array}$ & 24 & 20.87 & & & \\
\hline & Offering activity & 25 & 21.74 & & & \\
\hline & $\begin{array}{l}\text { Put forward the } \\
\text { idea for the activity } \\
\text { to take place }\end{array}$ & 58 & 50.43 & & & \\
\hline
\end{tabular}

\subsection{Observing The Children}

Observations were made to determine the interests, needs, and understanding of the child. All teachers actively observe children's activities. Do children touch, for example, whether the children touch the leaves, bark and motion. How the body expression (gesture) at the time of observing the tree. Does the child's activity help the child gain some knowledge? The results of the analysis show that almost all teachers do observations at the time of children doing learning activities in science learning. In fact, all teachers see the learning activities even though there are still teachers, as many as $13.04 \%$ of teachers have not listened to what children say when children do science learning activities. This observation is done by teacher to encourage children to do learning activity as exemplified by teacher.

Table 3. Observing The Children

\begin{tabular}{|c|c|c|c|c|c|c|}
\hline Teacher activity & Indicator & $\begin{array}{c}\text { Relative } \\
\text { Frequency } \\
\text { (sample } 115 \text { org } \\
\text { guru) } \\
\end{array}$ & $\begin{array}{l}\text { Persentag } \\
\text { e }(\%)\end{array}$ & $\begin{array}{l}\text { Ideal } \\
\text { mean }\end{array}$ & Mean & Sd \\
\hline $\begin{array}{l}\text { Observing the } \\
\text { children }\end{array}$ & $\begin{array}{l}\text { Pay attention to what the } \\
\text { child is doing }\end{array}$ & 115 & 100.00 & 1.5 & 2.81 & 0.53 \\
\hline
\end{tabular}




\begin{tabular}{lcc}
\hline $\begin{array}{l}\text { Pay attention to child } \\
\text { gestures }\end{array}$ & 108 & 93.91 \\
$\begin{array}{l}\text { Listen to what the child } \\
\text { says }\end{array}$ & 100 & 86.96 \\
\hline
\end{tabular}

\subsection{Asking Questions}

In the component of questioning, the results of the analysis are contradictory to the results of the analysis on the observing component of the child. Only $50.43 \%$ of teachers ask questions to children during learning activities. The results of the analysis on the content of the questions posed by teachers found that only $8.70 \%$ which contains questions that encourage children to think more critical and do more creative activities. This shows that teachers have not been successful in asking questions according to the characteristics required for science learning. Questions posed more charged mastery of the material that makes the child depressed so less even not focused. In fact, the questions raised in science learning aim to encourage children to explore objects [3]. Asking questions becomes one of the most important things in early childhood learning [19]. When the teacher asks questions, it is important to note the questions asked and the questions asked in the question. The content of the questions is expected to guide the children to focus on gaining the knowledge [1]. The questions may be asked when the children come for help; The teacher may respond by asking the right questions and by challenging the children [3]. This type of question is also known as guided question [17].

Table 4. Asking Questions

\begin{tabular}{|c|c|c|c|c|c|c|}
\hline $\begin{array}{l}\text { Teacher } \\
\text { activity }\end{array}$ & Indicator & $\begin{array}{c}\text { Relative } \\
\text { Frequency } \\
\text { (sample } 115 \text { org } \\
\text { guru) }\end{array}$ & $\begin{array}{l}\text { Persentage } \\
\quad(\%)\end{array}$ & $\begin{array}{l}\text { Ideal } \\
\text { mean }\end{array}$ & Mean & Sd \\
\hline \multirow{2}{*}{$\begin{array}{l}\text { Asking } \\
\text { questions }\end{array}$} & Provide questions for referrals & 58 & 50.43 & 1 & 0.59 & 0.65 \\
\hline & $\begin{array}{l}\text { Provide questions that encourage } \\
\text { children to see deeper / higher objects }\end{array}$ & 10 & 8.70 & & & \\
\hline
\end{tabular}

\subsection{Organizing The Environment}

Organizing the environment is one of the key components in determining the success of learning in constructivist approach [3]. The organization of the environment in this research was conducted in two learning environments, which were in and out of class (indoor and outdoor). Both environments might be alternately used or only one. Both environments needed to be organized in order to help the children concentrate or focus on the learning activities. The organization of the learning environment was not

Table 5. Organizing The Environment Teacher activity Indicator

$\begin{array}{lll}\begin{array}{l}\text { Organizing the } \\ \text { environment }\end{array} & \begin{array}{l}\text { Organize learning materials } \\ \text { according to the child's } \\ \text { (sample } \\ \text { org guru) } \\ \text { ratio:material }\end{array} \\ \text { Organize material in the } 115\end{array}$

merely related to the directly used materials; it was also related to the supporting components such as pictures and lightings. The teacher needed to design the placement of materials in order to attract the attention of the children. As much as $41.45 \%$ of teachers conducted the environmental organization, meanwhile the rest merely focused on organizing the materials and tools related to the learning activities. For example, during the learning activity of making orange juice, the teacher merely organized the fruit, juicer, and glasses. The pictures around the classroom were not organized.

$\begin{array}{lllll}\begin{array}{l}\text { Relative } \\ \text { Frequency } \\ \text { (sample } \\ \text { org guru) } \\ 24\end{array} & \begin{array}{l}\text { Persentage } \\ (\%)\end{array} & \begin{array}{l}\text { Ideal } \\ \text { mean }\end{array} & \text { Mean } & \text { Sd } \\ & 20.87 & 1.5 & 1.24 & 0.49 \\ 115 & 100.00 & & & \\ & & & & \\ \end{array}$


classroom

Arranging material outside the 4

3.48

classroom

\subsection{Managing the social interaction}

Social organization of interaction related to class organizing. Classroom organizing aims to provide opportunities for interaction between children and teachers, interaction between children with other children, the interaction of children with media and learning materials and learning atmosphere. The results showed that there were $93.91 \%$ of teachers organizing children according to the ratio of teachers: children, ie 1:15. But when viewed from the ratio of children: the class, amounting to $29.96 \%$ of teachers who organized the class according to the ratio of children: class. This difference occurs because in one class there are two teachers so that the ratio of teachers: children are fulfilled. In this way, teacher ratios: children are met, while class ratios: children and children: the media has not been met. As a result, the class becomes full, the children have difficulty to move from one activity to another activity, the child has difficulty using learning media together and communication with other child also difficult to happen. These results indicate that there is a mutual interaction between teacher and child behavior depending on the size of the class.

Table 6. Managing The Social Interaction

\begin{tabular}{|c|c|c|c|c|c|c|}
\hline $\begin{array}{l}\text { Teacher } \\
\text { activity }\end{array}$ & Indicator & $\begin{array}{l}\text { Relative } \\
\text { Frequency } \\
\text { (sample } 115 \\
\text { org guru) } \\
\end{array}$ & $\begin{array}{l}\text { Persentage } \\
(\%)\end{array}$ & $\begin{array}{l}\text { Ideal } \\
\text { mean }\end{array}$ & Mean & Sd \\
\hline \multirow[t]{5}{*}{$\begin{array}{l}\text { Managing the } \\
\text { social } \\
\text { interaction }\end{array}$} & $\begin{array}{l}\text { Place the child in the class } \\
\text { according to the proportion of the } \\
\text { child: class }\end{array}$ & 31 & 26.96 & 2.5 & 1.61 & 1.28 \\
\hline & $\begin{array}{l}\text { Placing children in class according } \\
\text { to the proportion of children: } \\
\text { teachers }\end{array}$ & 108 & 93.91 & & & \\
\hline & $\begin{array}{l}\text { Placement of children has the } \\
\text { opportunity to move places } \\
\text { /activities }\end{array}$ & 21 & 18.26 & & & \\
\hline & $\begin{array}{l}\text { Placement of children in the } \\
\text { classroom that makes it easier for } \\
\text { children to communicate }\end{array}$ & 17 & 14.78 & & & \\
\hline & $\begin{array}{l}\text { Placement of children makes it } \\
\text { easier for children to do activities } \\
\text { together with using learning } \\
\text { materials }\end{array}$ & 8 & 6.96 & & & \\
\hline
\end{tabular}

\subsection{Documenting}

Activities documenting all evidence of child learning activities and outcomes relate to observation activities. Documenting in learning is also part of the assessment. Data obtained by teachers in learning needs to be documented to determine child development and subsequent learning program preparation. In this documentation activities teachers need to compile, organize, use and share information relating to children, especially for children's self-development. The result of analysis shows that $20 \%$ of teachers do documentation and from this documentation activity, $13.04 \%$ of teachers use data for self-development of children and $7.83 \%$ of teachers share information to parents or stakeholders of children's self-development. This shows some teachers have not documented evidence of children's learning activities and outcomes. This happens because of various factors, among other factors Data that is distributed to parents often in the form of analysis results without the support of 
documents or evidence. Recordings were not completed specifically to the individuals and instead they were made in general. Such things would hinder the teachers during the reporting of the children's development. These results indicate that there are difficulties teachers conducting the assessment. FGD show results that they have difficulty making the instrument and taking notes in detail. Besides that, Children are unique and complex and so often difficult to comprehend [8].

Table 7. Documenting

\begin{tabular}{|c|c|c|c|c|c|c|}
\hline $\begin{array}{l}\text { Teacher } \\
\text { activity }\end{array}$ & Indicator & $\begin{array}{l}\text { Relative } \\
\text { Frequency } \\
\text { (sample } 115 \\
\text { org guru) }\end{array}$ & $\begin{array}{l}\text { Persentage } \\
(\%)\end{array}$ & $\begin{array}{l}\text { Ideal } \\
\text { mean }\end{array}$ & Mean & Sd \\
\hline \multirow[t]{4}{*}{ Documenting } & $\begin{array}{l}\text { Compiling evidence of activities and } \\
\text { learning outcomes of children for the } \\
\text { purposes of self-development of } \\
\text { children }\end{array}$ & 39 & 33.91 & \multirow[t]{4}{*}{2} & \multirow[t]{4}{*}{0.80} & \multirow[t]{4}{*}{1.29} \\
\hline & $\begin{array}{l}\text { Organizing evidence of activities and } \\
\text { learning outcomes of children for the } \\
\text { purposes of children's self- } \\
\text { development }\end{array}$ & 29 & 25.22 & & & \\
\hline & $\begin{array}{l}\text { Using evidence of activity and } \\
\text { learning outcomes of children in the } \\
\text { development of learning programs }\end{array}$ & 15 & 13.04 & & & \\
\hline & $\begin{array}{l}\text { Sharing information in accordance } \\
\text { with evidence of activities and } \\
\text { learning outcomes obtained by } \\
\text { children }\end{array}$ & 9 & 7.83 & & & \\
\hline
\end{tabular}

\subsection{Developing The Learning Culture}

Every individual (teacher, child, principal, and parent) has his or her own habit and such habit influences the learning. In order to develop the learning environment, the teacher needs to manage the interaction in learning so that a pleasant learning environment is created in supporting various learning activities. The results show that all teachers give examples of activities that children need to do.
But only some teachers $(55.65 \%)$ who provide reinforcement of learning activities undertaken by children. In addition, only a small percentage of teachers, as many as $19.13 \%$ of teachers who provide opportunities for children to demonstrate success obtained by children. Activity demonstrating the success of learning is an appreciation effort that is likely to motivate children to perform better learning activities.

Table 8. Developing The Learning Culture

\begin{tabular}{|c|c|c|c|c|c|c|}
\hline Teacher activity & Indicator & $\begin{array}{l}\text { Relative } \\
\text { Frequency } \\
\text { (sample } 115 \\
\text { org guru) }\end{array}$ & $\begin{array}{l}\text { Persentage } \\
(\%)\end{array}$ & $\begin{array}{l}\text { Ideal } \\
\text { mean }\end{array}$ & Mean & Sd \\
\hline \multirow[t]{3}{*}{$\begin{array}{l}\text { Developing the } \\
\text { learning culture }\end{array}$} & $\begin{array}{l}\text { Gives an example of what the } \\
\text { child needs to do in learning }\end{array}$ & 115 & 100.00 & 1.5 & 1.75 & 0.72 \\
\hline & $\begin{array}{l}\text { Provide reinforcement on } \\
\text { learning activities that have not } \\
\text { been maximized }\end{array}$ & 64 & 55.65 & & & \\
\hline & $\begin{array}{l}\text { Allowing children to } \\
\text { demonstrate positive behaviors }\end{array}$ & 22 & 19.13 & & & \\
\hline
\end{tabular}




\section{or learning activities Theories}

In this part, the teacher needs to be capable in playing the role of a scientist to assist the children to become scientists. In this part, the teachers still struggled to realize their roles in such activities that will help the children to become scientists. Based on the data investigation in FGD, it was discovered that the teachers tended to ignore this part. The teachers still struggled to play the role of a theory builder in learning. The teacher has the power to actively engage as scientists in learning activity. For example, during the activity of observing the "Trees" in the kindergarten yard, the teacher managed to encourage the student to actively conduct the observation. However, such observation have yet to be guided specifically so that the children have not learned the concepts of textures, forms, sizes, and colors of the trees yet. The teacher has not been able to ask guided questions such as "Look at this tree bark, touch and feel it. What about that tree bark? Let's touch and feel it again." The teachers have not been able to assist the children in such guided questions and, thus, have not successfully guided the children yet to compare and observe the textures. In another situation, a child observed another creature living on the trees such as ants and worms. The child asked, "Miss, look, there are worms. Miss, there are ants". Such questions were not properly responded and instead the teacher merely uttered 'oh yeah?', and even encouraged the child to go back looking at the tree whereas the child had lost interest in it. The teacher should have guided children to look at what the ants or the worms were doing, and the child might mention that the tree served as a 'home' to the ants or worms. When such thing happens, the child has the opportunity to understand the concept of roughness, softness, tallness, lowness, bigness, and smallness. The child may also understand the concept of worms, ants, and the child may understand the concept of 'home'. In the next day, when shown the cards with the pictures of worms and ants in them, the child may recall the memory of the tree that had texture, size, form, and color. And when the teacher mentions the word 'ant' during the next day, the child recalls the characteristics of the tree (Bruner Theory).

Table 9. Drawing up Conclusions of The Theories

\begin{tabular}{|c|c|c|c|c|c|c|}
\hline $\begin{array}{l}\text { Teacher } \\
\text { activity }\end{array}$ & Indicator & $\begin{array}{c}\text { Relative } \\
\text { Freque } \\
\text { ncy } \\
\text { (sample } \\
115 \text { org } \\
\text { guru) }\end{array}$ & $\begin{array}{c}\text { Persentage } \\
(\%)\end{array}$ & $\begin{array}{l}\text { Ideal } \\
\text { mean }\end{array}$ & Mean & Sd \\
\hline \multirow[t]{3}{*}{$\begin{array}{l}\text { Drawing up } \\
\text { conclusions of } \\
\text { the theories }\end{array}$} & $\begin{array}{l}\text { Encourage children to } \\
\text { express what knowledge } \\
\text { is acquired }\end{array}$ & 25 & 21.74 & 1.5 & 0.8 & 0.58 \\
\hline & $\begin{array}{l}\text { Encourage children to } \\
\text { make reports on science } \\
\text { activities }\end{array}$ & 20 & 17.39 & & & \\
\hline & $\begin{array}{l}\text { Encourage children to } \\
\text { present the results } \\
\text { obtained }\end{array}$ & 18 & 15.65 & & & \\
\hline
\end{tabular}




\section{CONCLUSION}

The Early childhood teachers need to understand and help children to become young scientists in science learning through a constructivist approach consisting of eight activities. The results of this study indicate that the eight science learning activities for early childhood conducted by teachers such as the following:

a) The all teachers prepare materials and learning materials for children, but teachers have not given children the opportunity to choose media and learning activities as desired,

b) The all teachers observe the child at the time of study, but not all teachers listen to children's talk so the teacher has not been caught The content of conversation between children in learning,

c) There are a small number of teachers asking questions to help children think critically,

d) There is a majority of teachers provide materials and learning media, but seen from the ratio of children: learning materials known that the comparison has not yet fulfilled the ratio of children: learning materials

e) Management of children's interaction with the learning component of the teacher has not been maximized especially when viewed from the opportunity of children to move places and the freedom to use media and learning materials in accordance with the needs of children,

f) Documentation management conducted by the teacher is still in the data acquisition stage. The data obtained by the teachers have not been compiled with one another, have not been managed and used in accordance with the assessment principles and have not been distributed with authorities to foster child development,

g) There is a learning culture development activities undertaken by the teacher, that is by giving examples of what learning activities need to be done by the child, but still a small percentage of teachers to give reinforcement of learning outcomes achieved by children,

h) There are all teachers who encourage children to gain some knowledge by asking the child to reveal the knowledge gained but still a small percentage of children who have the opportunity to present the resulting work.

\section{REFERENCES}

[1] Ali, Nugraha,. Pengembangan pembelajaran sains pada anak usia dini. Jakarta: Universitas Terbuka. 2005.

[2] Bowman, Barbara T.; Donovan, M. Suzanne; \& Burns, M. Susan (Eds.). Eager to learn: Educating our preschoolers. Washington, DC: National Academy Press. 2001.

[3] Christine, Chaille \& Lory, Britain. The Young child as scientist a constructivist approach to early childhood science education. Boston: Pearson Education. 2003.

[4] Chalufour, Ingrid and Karen Worth. Discovering nature with young children. Minnesota: Redleaf Press. 2003.

[5] Donna, M. Plummer, Jeannie MacShara, and Skila King Brown. The Tree of life Students began to make connections between humans and their actions and the rain forest and other environments, An NSTA Press Journals Collection Start Young! Early childhood science activities, Arlington Virginia: NSTApress National Science Teacher Association. 2006 .
[6] Dunkin, Michael J\& Biddle, Bruce J. TheStudy of teaching.USA:Holt, Rinehart and Winston,Inc. 1974.

[7] Feeney, Stephanie, Doris Christensen, and Eva, Moravik,. Who am I in the lives of children seventh edition. Columbus, Ohio: Pearson Merril Prentice Hall. 2006.

[8] George Forman \& Ellen Hall, (2005) Wondering with Children: The Importance of Observation in Early Education, Journal ECRP, Vol 7 No 2

[9] Gunawan, Adi, W. Genius learning strategy petunjuk praktis untuk menerapkan accelerated learning. Jakarta: Penerbit PT Gramedia Pustaka Utama. 2004.

[10] Jones, Vern. Louise Jones. Comprehensive Classroom Management Creating Communities of Support and Solving Problems Ninth Edition. Amerika: Bind-Rite. 2010.

[11] Joyce, Bruce dan Marsh,Weil,. Models of teaching. Fifth edition. Boston: Allyn and Bacon. 1996.

[12] Karen Worth. Science in early childhood classroom: content and process. Seed Paper, Newton, Massachusetts: Center for Science Education, Edducation Development Center, Inc. 2010.

[13] Kauchack, Donald P \& Eggen, Paul D. Learning and teaching research based methods. Boston: Pearson Education. 2008.

[14] Kemp, Jerrold, E. (1985). The Instructional design process. New York: Harper and Row Publisher

[15] Meier, C. and Marais, P. Educational management in early childhood development. Pretoria: Van Schaik Publishers. 2007

[16] Moore, Kenneth D. Effective Instructional strategies from theory to practice. London: sage Publication Ltd. 2005.

[17] Muslichach, Asy'ari,. Penerapan pendekatan Sains - Teknologi Masyarakat dalam pembelajaran sains di Sekolah Dasar, Jakarta: depdiknas Ditjend Dikti Direktorat Ketenagaan. 2006.

[18] Puckett, Margaret B. dan Deborah Diffily. Teaching Young Children Second Edition. Canada:Thomson Delmar Learning. 2004.

[19] Shannan, MacNair. Introduction. An NSTA Press Journals Collection Start Young! Early childhood science activities, Arlington Virginia: NSTApress National Science Teacher Association. 2006.

[20] Snelbecker, Glenn, E. Learning theory, instructional theory and psychoeducational design. New York: McGraw-Hill Book Co. 1974.

[21] Supriadi, Dedi. Membangun bangsa melalui pendidikan. Bandung: PT Remaja Rosdakarya. 2004. 